Електронне наукове фахове видання "Ефективна економіка" включено до переліку наукових фахових видань України з питань економіки (Категорія «Б», Наказ Міністерства освіти і науки України від 11.07.2019 № 975) www.economy.nayka.com.ua | № 5, 2021 | 27.05.2021 p.

DOI: $\underline{10.32702 / 2307-2105-2021.5 .6}$

УДК 334

S. Yermak

Doctor of Economic Sciences, Associate Professor, Associate Professor of the Department of Economics of Enterprises, Odessa Polytechnic State University

ORCID ID: 0000-0001-5232-6406

\title{
FORMATION OF INCLUSIVE BUSINESS THROUGH THE SOCIAL RESPONSIBILITY OF INNOVATIVE ENTERPRISES
}

\author{
С. О. Срмак, \\ д. е. н., дочент, доцент кафедри економіки підприємств, \\ Державний університет «Одеська політехніка»

\section{ФОРМУВАННЯ ІНКЛЮЗИВНОГО БІЗНЕСУ ЧЕРЕЗ СОЦАЛЬНУ ВІДПОВІДАЛЬНІСТЬ ІННОВАЦІЙНИХ ПІДПРИЕМСТВ}

In modern conditions, the problem of progressive socio-economic development, which provides a real increase in quality of life as a key indicator of the country's development and its competitiveness in world markets, becomes one of the priorities for the country as a whole and for enterprises in particular. The task for innovative enterprises is to choose such an optimal business model that would allow them to make a profit and at the same time act for the benefit of society while enterprises adhere to the basic principles and directions of corporate social responsibility. Inclusive business models (business models of social entrepreneurship) can act as such a business model for innovative enterprises. The aim of the article was to study the logic of inclusive business formation based on corporate social responsibility and models of social entrepreneurship and to develop the main directions of inclusive development of innovative enterprises. Research has shown that inclusive business empowers people living in poverty by adapting their core business or part of their core business to their needs. The introduction of inclusive business models can help to quickly introduce elements of corporate social responsibility or compliance with social and environmental standards by the company and support the population at the bottom of the social pyramid. The existing inclusive business models are analyzed and classified according to six features: innovation; applicability; inclusion of vulnerable populations; profitability; obtaining social and environmental effects. Because all variants of inclusive business models are innovative for enterprises, it was appropriate to identify the main areas of inclusive development of their innovation activities by four main types of innovations in their areas of use: process, product, technology and complex. To eliminate the possible destructive consequences of innovations, their negative impact on the environment, inaccessibility to remote areas and to enable the inclusion of all segments of the population in the innovation process, we have outlined the range of social responsibility of innovators. Thus, the introduction of inclusive business models will allow all parties involved to benefit from each other. Achieved synergy between the state, business, and the population, will lead to sustainable solutions, innovation, competitive advantage, better reputation, expanding market share, etc. And inclusive business, because of a developed corporate culture based on elements of compliance and corporate social responsibility, will be an effective tool for 
socio-economic progress both at the state level and at the business level, which can improve the quality of life.

В сучасних умовах проблема прогресивності сочіально-економічного розвитку, який забезпечує реальне зростання якості життя людей як основного індикатора розвитку краӥни та ї конкурентоспроможності на світових ринках, набуває першочергової актуальності й стає одним з пріоритетних напрямків розвитку як для краӥни в цілому, так $i$ для підприємств зокрема. Для інновачійних підприємств постає завдання вибору такої оптимальної бізнес-моделі, щзо дозволила би їм отримувати прибуток та при цььому діяти на благо суспільства при дотриманні підприємствами основних принципів $i$ напрямків розвитку корпоративної соціальної відповідальності. У вигляді такої бізнес-моделі для інновачійних підприсмств можуть виступити саме інклюзивні бізнес-моделі (бізнес-моделі соціального підприємництва). Метою статті виступило дослідження логіки формування інклюзивного бізнесу на основі корпоративної соціальної відповідальності та моделей сочіального підприємництва й розробка основних напрямів інклюзивного розвитку інновачійних підприємств. У ході дослідження доведено, щуо інклюзивний бізнес розширює можливості людей, які живуть у злиднях, пристосовуючи основний бізнес або частину основного бізнесу до їхніх потреб. Впровадження моделей інклюзивного бізнесу може допомогти швидкому введенню елементів корпоративної соціальної відповідальності або дотриманню соціальних та екологічних стандартів з боку підприємства та підтримки населення, щуо знаходиться в основі сочіальної піраміди. Проаналізовано існуючі інклюзивні бізнес-моделі та класифіковано їх за шістьма ознаками: інноваційністю; застосовністю; включенню вразливих категорій населення; прибутковістю; отриманням сочіального та екологічного ефектів. Виходячи з того, що, усі варіанти інклюзивних бізнес-моделей $є$ по суті інновачійними для підприємств, доцільним стало виділення основних напрямів інклюзивного розвитку їх інноваційної діяльності за чотирма основними видами інновацій за сферами їх використання: процесними, продуктовими, технологічними та комплексними. 3 метою усунення можливих деструктивних наслідків інновацій, їх негативного впливу на екологію, недоступності для віддалених територій та задля надання можливості включення усіх верств населення до інноваційного процесу нами було окреслено коло соціальної відповідальності інноваторів. Отже, впровадження інклюзивних бізнес-моделей дозволить усім залученим сторонам отримати взаємну вигоду. Досягнута синергія між державою, бізнесом і населенням, призведе до стійкого вирішення проблем, інновацій, конкурентних переваг, кращуої репутації, розширення частки ринку і т.п. А інклюзивний бізнес, як наслідок розвиненої корпоративної культури на базі елементів комплаєнсу $і$ корпоративної сочіальної відповідальності, стане дієвим засобом для соиіально-економічного прогресу як на рівні держави, так і на рівні бізнесу, щэо здатний підвищити якість життя населення.

Key words: corporate social responsibility, business structure, development, innovation activity.

Ключові слова: інклюзивний бізнес, соціальне підприємництво, корпоративна сочіальна відповідальність, інклюзивні бізнес-моделі, інноваційні підприємства.

Problem statement. In a post-industrial, globalized world, the problem of progressive socio-economic development, which provides real growth in people's quality of life as a key indicator of the country's development and competitiveness in world markets, becomes paramount and becomes one of Ukraine's priorities. The general goal of socio-economic development, socio-economic policy of the state, economic and political reforms is to improve people's lives. Human interests - this is the criterion according to which it is necessary to assess any processes in the economic, social, and political life of the country. Futurological projects on the progressiveness of the information economy and post-industrial development have already been destroyed by the harsh reality of lack of financial and material resources on world markets, which only leads to increased competition. Recent experience has shown that rapid scientific and technological progress, modernization of the economy and economic growth may be accompanied by rising income inequality, social inequalities, and growing disparities between urban and rural areas. These tendencies actualize the 
problems of social stratification in the process of development. Thus, the task is to choose for innovative enterprises such an optimal business model that would allow them to make a profit and at the same time act for the benefit of society while enterprises adhere to the basic principles and directions of corporate social responsibility. Inclusive business models can become as such a business model for innovative enterprises.

Analysis of recent research and publications. The study of some elements of inclusive business for several decades has not lost its relevance both in world and in Ukrainian scientific research. For example, the works of such scientists as S. Filippova [15; 16; 19]; P. Voronzhak [16]; Bowen H. [17]; Porter M.E. and Kramer M.R. [18]; M. Sukhoterina [19]; Jamali D. [20], Frolova L. [25]. The novelties and subtleties of compliance were studied by: P. Pererva [10]; A. Dziuba [11]; N. Ovsyuk [12]; T. Momot and I. Kolyada [13]; Shazia S. and Guido G. [14]. In some sources $[1 ; 2 ; 6 ; 21]$, "social entrepreneurship" is synonymous with inclusive business. Business models of social entrepreneurship [1;2;6] and inclusive business models [7; eight; nine; 22; 23; 24], the name of which arose due to the actualization of the concept of "inclusive development" $[3 ; 27 ; 28]$ are also recognized in world practice as the basis of inclusive business and effective functioning of innovative enterprises $[3 ; 4 ; 5 ; 26]$. There are some problems of introducing such models into the activities of innovative enterprises in Ukraine due to their insufficient popularization, lack of understanding of the benefits and fears of enterprises using them. That affects the speed and quality of the formation of an inclusive business in Ukraine.

Research objective. The purpose of the article is to explore the logic of forming an inclusive business based on corporate social responsibility and models of social entrepreneurship and to develop the main directions of inclusive development of innovative enterprises.

Presentation of the main research material. Often, companies that have chosen the direction of inclusive development are called social. Meaning that their goal is not to make a profit, but this is not the case. Although charity, philanthropy and corporate social responsibility have common features with inclusive business models. This term in many cases corresponds to a narrow definition of social entrepreneurship. If solving the problem of poverty and maximum inclusion of all segments of the population and all territories is part of the task of such an enterprise (person).

Under social entrepreneurship we will understand entrepreneurial activity aimed at positive innovative changes in society: mitigation or solution of social problems at the expense of income from their own activities. And we will call inclusive enterprises those that have implemented inclusive business models in their activities. Inclusive business model of Western economists $[6 ; 7 ; 8 ; 9 ; 27 ; 28]$ is interpreted as a commercially viable model that benefits low-income communities, including them in the value chain of the enterprise on the demand side as customers and consumers and / or on the supply side as producers, entrepreneurs, or employees on a sustainable basis.

The logic of forming an inclusive business in connection with corporate social responsibility can be depicted in more detail (Fig. 1).

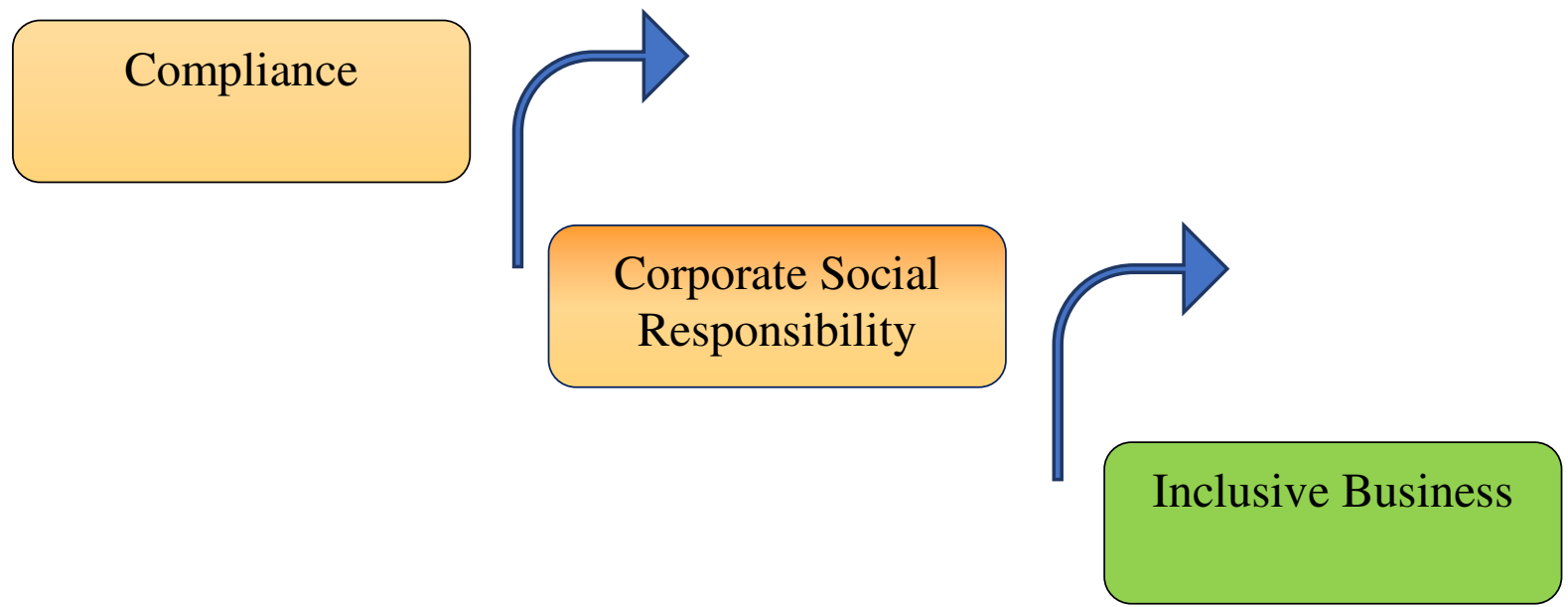

Figure 1 - The logic of an inclusive business forming Source: developed by the author

The term "compliance" appeared relatively recently in business circles of Ukraine and in the circle of interests of scientists $[10 ; 11 ; 12 ; 13 ; 14]$, as defined by international organizations, it describes the abidance of enterprises with laws and regulations and voluntary codes of conduct. This applies, for example, to international and domestic labor standards, environmental legislation and standards, or the establishment of anti-corruption measures to reduce the negative social or environmental consequences of the company's core business.

Corporate social responsibility (CSR) has also recently come to the circle of research of foreign and domestic scientists $[15 ; 16 ; 17 ; 18 ; 19 ; 20 ; 21 ; 25]$ and means economically, socially, and environmentally responsible business practices and is consistent with the concept of sustainable economic development. Businesses are committed to respecting social and environmental principles, as well as human rights, in their daily activities and in their dealings with employees, shareholders, consumers, investors and civil society.

Often such a business model is needed by new markets to protect consumers, where regulation does not yet exist to the necessary extent and there is no sustainable business model. And one-time solutions can create threats of 
various kinds, such as environmental. The introduction of inclusive business models can help the rapid introduction of CSR elements or compliance with social and environmental standards by the company and the support of the population at the heart of the social pyramid.

According to the definition of the World Bank: «Inclusive business empowers people living in poverty by adapting their core business or part of their core business to their needs. It may include compliance as well as elements of CSR, although this is not necessarily the case. Inclusive businesses are companies that develop innovative ways to do commercially-viable business with people living at the base of the pyramid (BoP) and to expand access to basic products and services» (by WBG).

The term "inclusive business" was introduced in 2005 by the World Business Council for Sustainable Development (WBCSD), but the phenomenon of inclusive business models is not new as such. Foreign companies have already had examples of successful inclusion of the lower social strata in their business models many years before the invention of this term. Today, many businesses use what we call inclusive business models without defining themselves as "inclusive business".

Inclusive business models create potential for businesses both in terms of profit and to meet social interests. Often the state does not have the resources, capacity or will to provide the necessary goods and services for the poor or in remote areas. In contrast, through the implementation of inclusive business models, companies can take advantage of opportunities to develop their innovative activities and create innovative solutions needed to serve remote areas that are traditionally considered inaccessible; provide access to products or services and increase the purchasing power of the poor by offering relevant goods and services at lower prices; use payment schemes that improve availability; create jobs and income by integrating the excluded into the value chain as distributors, suppliers or employees. Moreover, the focus on profit helps to ensure long-term financial stability of enterprises.

At the same time, the introduction of inclusive business models in local enterprises in the form of integration of local producers and micro-enterprises can provide additional benefits. From the point of view of private sector development - mainly micro, small, and medium enterprises - in the form of job creation, increased income, and certain benefits from the state by reducing tax payments, which in turn will help reduce poverty and improve the welfare of the society.

Back in 2006, S. Alter, A. Nicholls and their colleagues in their most cited work "Social Entrepreneurship: New Models of Sustainable Social Change" [2] gave examples of inclusive business models (or business models of social entrepreneurship) (Fig. 2).

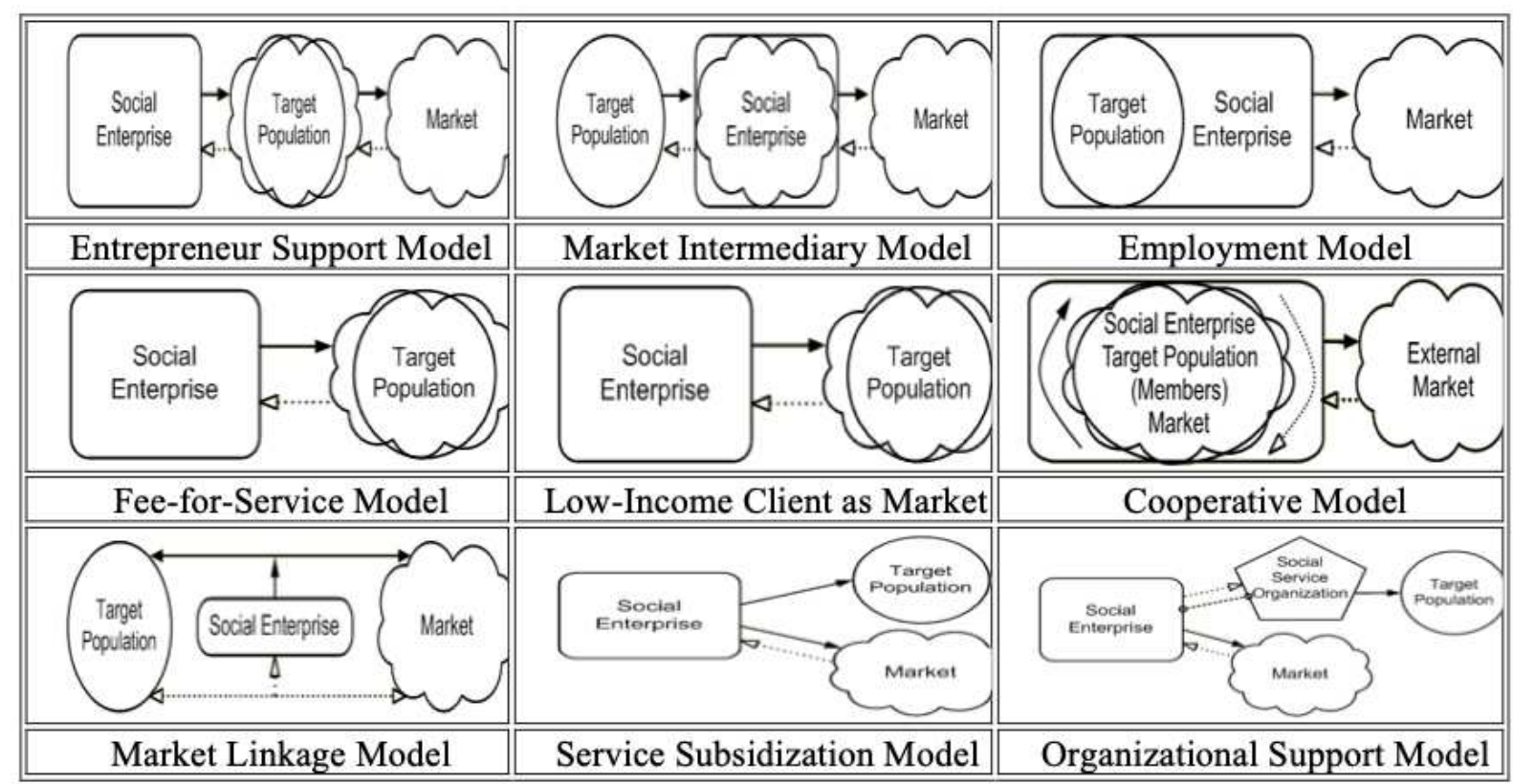

Figure 2 - Business models of social enterprises

Source: grouped by Wolfgang Grassl [1]

Their analysis was based on the ratio of the three main factors of social business (enterprise mission, type of integration and target groups). Among the inclusive business models operating in practice in Ukraine and in the world in the scientific report of the State Institution "Institute of Regional Research named after M.I. Dolishniy of the NAS of Ukraine (Dolishniy Institute of Regional Research of NAS of Ukraine) [21] describes 13 existing models (many of them are repetitions of previous researchers and are already known):

1) employment model provides employment and training opportunities for vulnerable groups: socially vulnerable groups, youth, anti-terrorist operation veterans, villagers, etc. This business model can often be complemented by additional social support services that create an enabling work environment for employees: 
vocational training, interpersonal skills training, physical therapy, mental health counseling, or temporary placement. The most popular business formats - shops, cafes, bakeries, woodworking enterprises;

2) fee-for-service model provides for the commercialization of social services and their sale (at an affordable price) or directly to representatives of vulnerable target groups, or enterprises, communities, third-party payers, the state. Typical examples of social enterprises of this model: organizations in which membership fees are paid, trade associations;

3) market intermediary model provides access to goods or services (targeted at a certain group of people who agree to pay for exclusive goods or services, the production of which involves people with special needs), which the market does not offer en masse, for example, agricultural products for vegans, etc.). The market intermediary either buys products produced by customers (vulnerable groups) or buys a large batch and then sells them in retail markets. The mission of companies working on this model is to strengthen the financial security of customers, assistance in the development and sale of their products. The market intermediation model is often used by social enterprises in agriculture, handicrafts and marketing;

4) entrepreneur support model provides that the social enterprise provides financial and other business support services to its target audience: businesses and private entrepreneurs. Then customers sell their goods and services on the open market. Types of enterprises that use this model: financial institutions, consulting agencies, institutions that provide professional services (accounting, legal and market information), technologies and products that support entrepreneurs;

5) service subsidization model provides for the use of income from the sale of goods or services to finance their social programs. The service financing model is usually integrated, then business activities and social programs intersect, and assets, operating income and expenses are distributed. Financing services are one of the most common models of social enterprises, as they can be combined with any non-profit organization. Owners of intangible assets, such as expertise, methodology or exclusive business relationships, can run any number of companies in various fields (consulting, logistics, marketing, etc.) that commercialize these assets. Owners of tangible assets (buildings, equipment, land, computers, etc.) can manage any number of enterprises that use these assets: leasing, asset management, retail; transportation, printing, etc. This model is very often combined with other business models. In addition, this model is somewhat similar to the traditional business model with a large share of capital aimed at corporate social responsibility and support for social projects;

6) development of the territory around the product (solves social problems of development of the territory of localization of the enterprise). The social enterprise works in the city and for the development of the city community. These are cafes, coworking spaces, centers for helping people in need and animals. The activities of such social enterprises lay certain practical foundations for solving social problems and improving the pleasant living conditions of citizens, the formation of their belonging to the local community;

7) construction of a platform (online and offline platform for finding consumers for small and medium-sized businesses that focus on social services). This model is very similar to the model of the market intermediary. It is differing in the way of support and formation of the marketing channel, forms social technological platforms and contributes to the consolidation of the population in the digital economy;

8) use and processing of waste (focused on collecting things from the population to give them a new purpose). This model involves in solving environmental and social problems, contributes to the preservation of the environment and forms the economical use and redistribution of resources;

9) cooperative model provides services to members of the cooperative: marketing research, technical assistance, collective bargaining and lobbying, savings on wholesale purchases, providing access to products and services, access to foreign markets, sales of goods and services within the cooperative, etc. Cooperatives often consist of small producers of one product group, or a community of people with common needs (access to capital, health care, etc.). The model includes, in particular, agricultural cooperatives that sell the products of its members, credit unions;

10) low-income client as market model is a variation of the model of paid services (Fee-for-Service model) and provides for the sale of goods and services to people who can meet only their basic needs, the poorest people. The model provides access to products and services that improve health, education, quality of life and personal capabilities of customers. However, due to the low income of the target audience in this model, achieving financial stability can be a challenge. Social entrepreneurship should be based on the development of creative distribution systems, reducing production and marketing costs, achieving high operational efficiency, effective presence in creative markets, etc.;

11) market linkage model involves the development of trade relations between the target audience: small producers, local companies, cooperatives, and foreign markets. A social enterprise acts as an intermediary that connects customers with producers and vice versa, for which it receives a "salary". Unlike the market intermediary model, this type of social enterprise does not sell products to consumers but connects consumers with markets. Many trade associations, cooperatives, public-private partnerships and business development programs operate on a "connected market" model;

12) organizational support model provides for the sale of goods and services on the foreign market to a wide range of buyers. In some cases, clients may be representatives of a socially vulnerable group. The model envisages the main business activities separately from the program, which has a social impact. Profits from the activities of the social enterprise are used to finance the costs of the social program and operating costs of the non-profit parent organization. This model of social enterprise works as a financing mechanism for the organization and often acts as an ancillary business of the non-profit parent organization; 
13) combined business models. To achieve a higher level of social influence, fundamental models can be combined.

I. Riepina [22; 23] emphasizes the benefits of using inclusive business models by enterprises, which is contained not only in direct profit, but also in attracting new customers, expanding employment, and strengthening the supply channels of raw materials and goods. The author proposed other types of inclusive business models:

- consulting and animation model, which provides for the dissemination of successful experience of innovative entrepreneurship among an inclusive audience by the entrepreneurs themselves. They provide advice on starting their own business, which then sells their innovative products or services on the open market;

- venture model in which large innovative enterprises or innovative entrepreneurs can participate in co-financing or lending their own creative work to poor people;

- job placement model, according to which enterprises provide employment and vocational training to people who cannot create competition in the traditional labor market (people with disabilities, the homeless, vulnerable youth, former convicts). This model is widely used by European public organizations of various directions, as well as urban development companies, cafes, courier companies, etc.;

- a philanthropic model in which entrepreneurs sell goods and provide services, and use the proceeds almost entirely to finance social programs (including the European Aid Fund for the Poor). However, the existence of such a model has been repeatedly criticized by a large number of entrepreneurs due to contradictions with competition law;

- a communication model that is often used to commercialize social services or to benefit from intangible assets such as trade relations, and entrepreneurs' income is spent on financing services to customers who are unable to pay for them.

Summing up the study of inclusive business models, there is an urgent need to classify them to subordinate and systematize. Therefore, we propose to classify the considered models on six grounds: 1) innovation; 2) applicability; 3) inclusion of vulnerable categories of the population; 4) profitability; 5) obtaining social and 6) environmental effects (Table 1).

Table 1.

Classification of inclusive business models of entrepreneurship

\begin{tabular}{|c|c|c|c|c|c|c|}
\hline Inclusive business models & 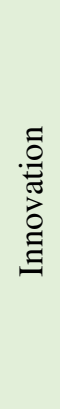 & 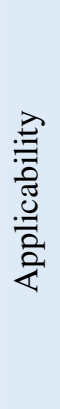 & 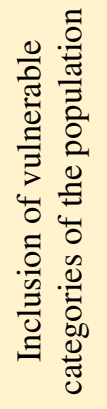 & 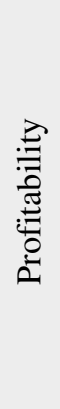 & 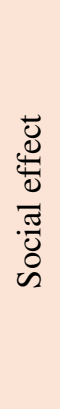 & 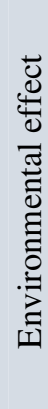 \\
\hline 1 & 2 & 3 & 4 & 5 & 6 & 7 \\
\hline 1. The employment model & + & + & + & + & + & \\
\hline 2. The fee-for-service model & + & + & + & + & + & \\
\hline 3. The market intermediary model & + & + & + & + & + & \\
\hline 4. The entrepreneur support model & + & + & + & + & + & \\
\hline 5. The service subsidization model & + & + & & & + & \\
\hline $\begin{array}{l}\text { 6. Development of the territory around the } \\
\text { product }\end{array}$ & + & + & & + & + & \\
\hline 7. Construction of a platform & + & + & & + & + & \\
\hline 8. Use and processing of waste & + & + & + & & + & + \\
\hline 9. The cooperative model & + & + & + & + & + & \\
\hline 10. Low-income client as market model & + & + & + & & + & \\
\hline 11. The market linkage model & + & + & + & + & + & \\
\hline 12. The organizational support model & + & + & + & + & + & \\
\hline 13. The consulting and animation model & + & + & + & & + & \\
\hline 14. The venture model & + & + & + & & + & \\
\hline 15. The philanthropic model & + & + & + & & + & \\
\hline 16.The job placement model & + & + & + & + & + & \\
\hline 17. The communication model & + & + & + & & + & \\
\hline 18. A combined business models & + & + & + & + & + & + \\
\hline
\end{tabular}

Source: systematized by the author for $[1 ; 2 ; 3 ; 6 ; 7 ; 8 ; 9 ; 21 ; 24 ; 27 ; 28]$ 
Because all variants of inclusive business models are essentially innovative for enterprises (Table 1), it is advisable to identify the main areas of inclusive development of their innovative activities by four main types of innovation in their areas of use: process, product, technological and complex (Fig. 3).

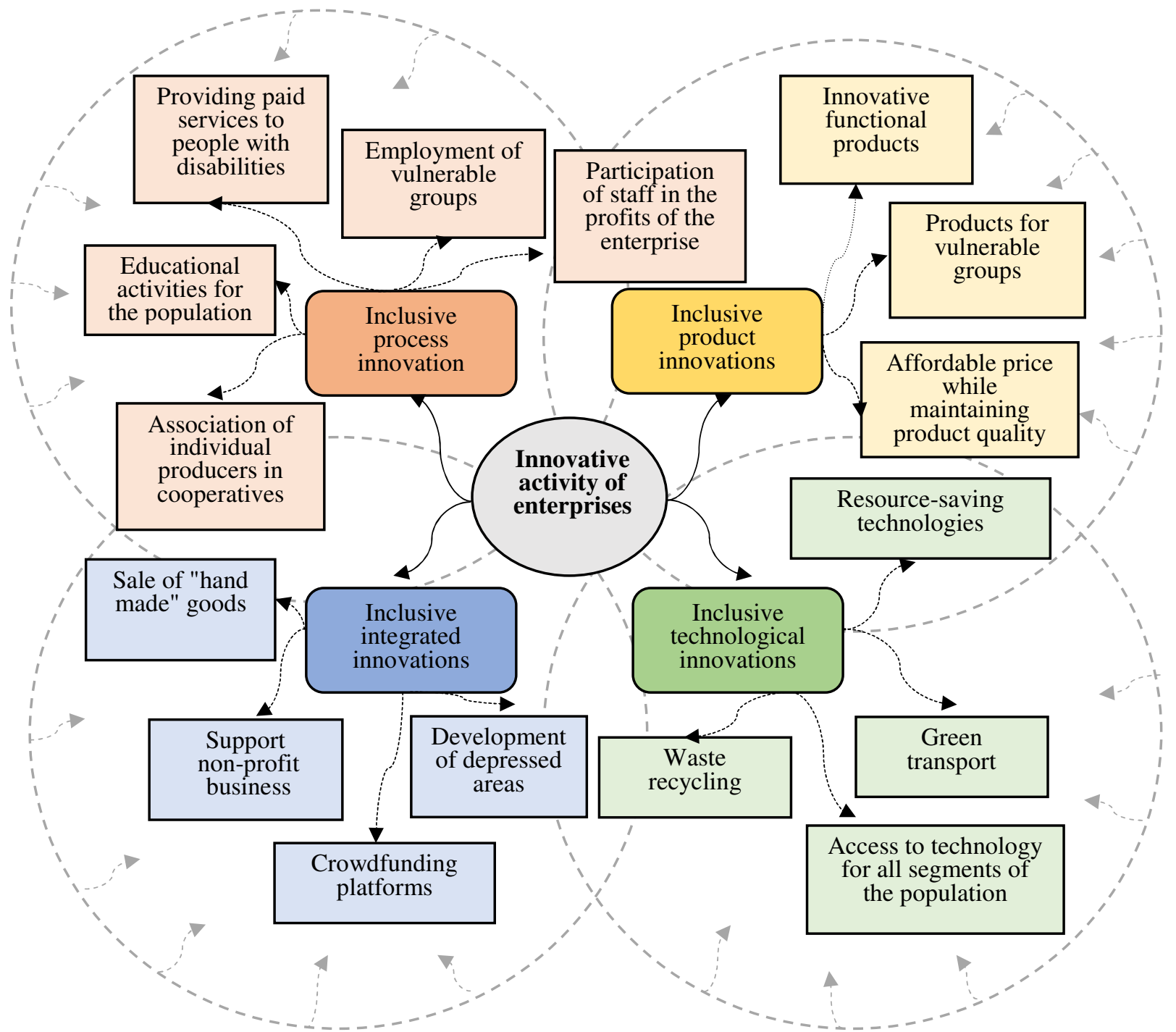

circle of social responsibility of innovators

Figure 3 - Directions of inclusive development of enterprises innovative activity Source: developed by the author

So, 1) the group of inclusive product innovations includes:

- innovative functional products;

- products for vulnerable groups;

- affordable price while maintaining product quality);

2) group of inclusive technological innovations:

- resource-saving technologies;

- "green transport";

- accessibility to technologies of all segments of the population;

- waste processing;

3) group of inclusive process innovations:

- association of individual producers in cooperatives;

- educational activities for the population;

- providing paid services to people with disabilities;

- employment of vulnerable groups;

- participation of staff in the profits of the enterprise;

4) group of complex inclusive innovations:

- development of depressed areas;

- crowdfunding platforms; 
- ancillary non-profit business;

- sale of "hand made" goods.

To eliminate the possible destructive consequences of innovations, their negative impact on the environment, inaccessibility to remote areas and to enable the inclusion of all segments of the population in the innovation process, we have outlined the range of social responsibility of innovators.

Conclusions. Summing up, we can say that now there are objective prerequisites for the inclusive development of the economy, enterprises, and their innovation. That is, these processes are already taking place in society and there is an urgent need for a detailed study of the phenomenon of "the concept of inclusive development", evaluation of the effectiveness of innovation in terms of its implementation and development of appropriate methodology. Accordingly, society demands inclusive models of enterprise and innovation. The analysis proved that all options for inclusive business models are available

In essence, innovative for enterprises, so it was appropriate to identify the main areas of inclusive development of their innovative activities in four main types of innovation in the areas of their use: process, product, technological and complex.

Also, inclusive business models allow all parties involved to reap mutual benefits. A certain synergy between the state, business and the population lead to sustainable problem solving, innovation, competitive advantages, better reputation, market share expansion, etc. And inclusive business, as a result of a developed corporate culture based on elements of compliance and corporate social responsibility, is an effective means for socio-economic progress both at the state level and at the business level, which can improve the quality of life of the population.

\section{References.}

1. Grassl, W. (2012) Business Models of Social Enterprise: A Design Approach to Hybridity. ACRN Journal of Entrepreneurship Perspectives, vol. 1, is. 1, pp. 37-60.

2. Alter, S. (2006), "Social Enterprise Models and Their Mission and Money Relationships". In A. Nicholls (ed.), Social Entrepreneurship: New Models of Sustainable Social Change. Oxford: Oxford University Press, pp. $205-232$.

3. Yermak, S.O. (2019), Theoretical and methodological basis of strategic management of inclusive development of enterprises innovative activity: [monograph], Time Realities Scientific Group UG (haftungsbeschränkt), Schweinfurt, Germany.

4. Yermak, S. (2017), "Problems of innovative activity development at food industry enterprises of Ukraine", Journal of Hygienic Engineering and Design, no. 21, pp. 96-102.

5. Vasiutkina, N., Boiko, O., Bavyko, O. and Yermak S. (2019), "The state and ways of Ukrainian food industry development in terms of integration into European economic space", Journal of Hygienic Engineering and Design, no. 27, pp. 69-86.

6. United Nations Development Programme (2008), "Creating Value for all: Strategies for Doing Business with the Poor", available at: https://www.rw.undp.org/content/rwanda/en/home/library/poverty/creating-value-for-all--strategies-for-doing-business-with-the-.html. (Accessed 30 April 2021).

7. Gradl, C. and Knobloch, C. (2009), How to develop Business and Fight Poverty. Inclusive Business Guide, ENDEVA, Berlin, Germany.

8. United Nations Development Programme (2010), “New Report on Inclusive Business Models' Contribution to the MDGs and Supporting Actors", available at: http://www.growinginclusivemarkets.org/mdgreport (Accessed 30 April 2021).

9. International Finance Corporation (2011), “Accelerating Inclusive Business Opportunities: Business Models that Make a Difference", available at: https:/www.ifc.org/wps/wcm/connect/e3d1d624-e381-4f1b-b997a5b81b929a33/ Pub_001_IFC_2011_FLAGSHIP.pdf?MOD=AJPERES\&CVID=1K6Z-UY (Accessed 30 April 2021).

10. Pererva, P.G. (2017), "Compliance program of an industrial enterprise: essence and tasks", Visnyk Natsionalnoho tekhnichnoho universytetu "KhPI". Seriia: Ekonomichni nauky : zbirnyk naukovykh prats, no.24 (1246), pp. 153-158.

11. Dziuba, A.Yu. (2019), "Anti-corruption compliance as a component of enterprise risk management", Forum Prava, no.54 (1), pp. 23-31.

12. Ovsyuk, N.V. (2018), "Compliance control in the field of labor relations" Hlobalni ta natsionalni problemy ekonomiky, no. 23, pp. 662-677.

13. Momot, T.V. and Kolyada I.V. (2017), "Compliance control in the system of financial security of banking institutions: status, problems, prospects", Suchasnyi stan naukovykh doslidzhen ta tekhnolohii v promyslovosti, no. 2 (2), pp. 124-131.

14. Shazia, S. and Guido, G. (2015), "Managing Regulatory Compliance in Business Processes", Handbook on Business Process Management 2, pp. 159-175.

15. Filippova, S.V. (2017), "Social responsibility in the management strategy of a domestic enterprise: problematic issues of mechanism integration", Ekonomika: realii chasu, no. 2 (30), pp. 5-17.

16. Filippova, S.V. and Voronzhak, P.V. (2015), "Innovative development of domestic industrial enterprises: main problems and trends", Ekonomichni innovatsii : Zbirnyk naukovykh prats, Is. 60, vol. 3, pp. 336-341.

17. Bowen, H. (1953), Social responsibilities of the businessman, Harper \& Row, New York, USA. 
18. Porter, M.E. and Kramer, M.R. (2006), “Strategy and Society: The Link Between Competitive Advantage and Corporate Social Responsibility”, Harvard Business Review, no.12, pp. 78-92.

19. Filippova, S.V. and Sukhoterina, M.I. (2015), "Comparative characteristics of methods for assessing the effectiveness of the system of corporate social responsibility of the machine-building enterprise", Biznes Inform, no. 3, pp. 284-287.

20. Jamali, D. (2018), “Corporate Social Responsibility in Developing Countries”, International Journal of Management Reviews, vol. 20, pp. 32-61.

21. Melnyk, M.I. (2019), "Inclusive dimension of development of cities - centers of business activity of Ukraine: tendencies and prospects: Scientific report", Seriia «Problemy rehionalnoho rozvytku», DU «Instytut rehionalnykh doslidzhen imeni M. I. Dolishnoho NAN Ukrainy», Lviv, Ukraine.

22. Riepina, I.M., Andriushchenko, K.A. and Kolomiyets-Ludwig, E.P. (2016), "Inclusive innovative

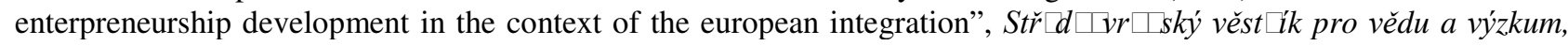
no. 1 (32), pp. 43-49.

23. Riepina, I.M. (2017), "European Inclusive Entrepreneurship: Applied Poverty Reduction Tools", Yevropeiski studii v Ukraini: zdobutky, vyklyky ta perspektyvy [European Studies in Ukraine: Achievements, Challenges and Prospects], Materialy mizh nar. nauk.-prakt. konf. [Materials between the people. scientific-practical conf.], Kyiv, Ukraine, pp. 282-286.

24. Food and Agriculture Organization of the United Nations (2017), "Inclusive Business Model. Training modules", no. 3 (17), pp. 79-82.

25. Frolova, L. and Yermak, S. (2021), "Development of corporate social responsibility among business structures of Ukraine", Efektyvna ekonomika, [Online], vol. 4, available at: http://www.economy.nayka.com.ua/?op=1\&z=8830 (Accessed 30 April 2021).

26. Frolova, L., Zhadko, K., Ilyash, O., Yermak, S., \& Nosova, T. (2021), "Model for opportunities assessment to increase the enterprise innovation activity", Business: Theory and Practice, vol. 22(1), pp. 1-11.

27. Gupta, J., Baud, I. et. al. (2014), "Sustainable Development Goals and Inclusive Development". POST2015/UNU-IAS Policy Brief \#5. Tokyo: United Nations University Institute, available at: https://collections.unu.edu/eserv/UNU:2567/ Post2015_UNUIAS_PolicyBrief5.pdf. (Accessed 30 April 2021).

28. Gupta, J., Pouw, N. and Ros-Tonen, A. (2015). Towards an Elaborated Theory of Inclusive Development. European Journal of Development Research, vol. 27 (4), pp. 12-15. pp.192-197.

29. Natorina, A.A. (2015), "Innovative development of Ukrainian enterprises", Nauka i sovremennost, no. 40, 